\title{
3 Ruashi, a Pessac in Congo? On the Design, Inhabitation, and Transformation of a 1950s Neighborhood in Lubumbashi, Democratic Republic of the Congo
}

\section{Introduction}

In the 1950s, the Office des Cités Africaines (OCA) built a number of neighborhoods for Africans around the major cities of Congo, Rwanda, and Burundi, at the time all territories under Belgian rule. ${ }^{1}$ Built within the broader context of the first Ten-Year Plan for the Economic and Social Development of the Belgian Congo (1949-1959), these "satellite cities" were conceived as a direct response to the emergence of bidonvilles or slums in urban centers like Kinshasa, Lubumbashi, Kisangani, or Bujumbura during the immediate postwar years. Evoking the motto Vers l'Avenir that underscored the then policy of the colonial government, these neighborhoods were celebrated in the national and international architectural press of the time as a successful example of the application of modern architectural and urban design principles to the urgent housing needs in Central Africa. The OCA cités featured prominently in a survey

\footnotetext{
1 A preliminary version of this paper was first presented at the 4th European Conference on African Studies (ECAS), Uppsala, 15-18 June 2011. The paper draws on research conducted in the context of the FWO-funded project "City, architecture and colonial space in Matadi and Lubumbashi, Congo. A historical analysis from a translocal perspective” (FWO n G.0786.09N, 2009-2012; main researcher: Sofie Boonen; main supervisor: Johan Lagae; co-supervisors: Baz Lecocq, Ghent University; Jacob Sabakinu, University of Kinshasa; Donatien Dibwe, University of Lubumbashi). Moreover, this paper benefitted in a substantial way from the unpublished master's dissertation of Céline Fenaux, "L’Office des Cités Africaines in Lubumbashi. Ruashi. Architecturale analyse en studie van de toe-eigening van een Congolese wijk uit de jaren 1950" (Ghent University, 2010; supervisors: Johan Lagae \& Sofie Boonen, Ghent University). We sincerely want to thank professor Donatien Dibwe dia Mwembu and assistant Serge Songa Songa Mitwa of the University of Lubumbashi, whose help has been crucial during all our fieldwork trips in Lubumbashi over the many years of research since 2000, and especially those missions in 2006, 2008, and 2010 during which Johan Lagae, Sofie Boonen, and Céline Fenaux investigated the Ruashi neighborhood
} 
documenting the achievements of the Ten-Year Plan that was published in 1950 under the title Investir c'est prospérer. ${ }^{2}$

In quantitative terms, however, the OCA cités did not provide a real solution, as the albeit impressive number of houses that were actually built remained far too limited to cover actual needs. Moreover, the OCA houses proved to be too expensive to be affordable for the targeted African inhabitants. Finally, as they were modeled on the modest single-family home in Belgium, their design did not meet the dwelling needs and practices of the common African household. No surprise then that the OCA neighborhoods have undergone major transformations over time. Parts of the original public spaces of the OCA cités have been re-appropriated or even privatized, and original OCA-type houses have in many cases been radically altered through the addition of informal structures.

In this chapter, we will focus on one particular example, the Ruashi neighborhood, built by the Office des Cités Africaines in the mining city of Lubumbashi. We will map its design phase with its underlying ideological agenda of colonial social engineering as well as modes of inhabitation and transformation, illustrating how the urban landscape of this particular OCA cité speaks of the manifold ways in which its inhabitants have responded to a physical environment shaped according to western dwelling patterns that were introduced in the context of colonialism. Instead of reading this transformed urban landscape in terms of a failed modernist project, let alone as an act of resistance against an imposed colonial order, we will approach it as an example of an "actively lived-in architecture,” in line with Philippe Boudon's famous 1969 study of Le Corbusier's Cité Frugès in Pessac. ${ }^{3}$ Doing so, we argue, opens up alternative ways of thinking the future of the OCA cités as an African, rather than as a mere colonial built, legacy.

\section{Countering the bidonville}

As in many other colonies, the Second World War gave rise to a massive migration wave of Africans from the hinterlands to the main urban centers of the Belgian Congo. Large enterprises based in the cities significantly increased the number of recruited African workers to respond to a booming economy in

2 Georges J. Plumier, ed., Investir c'est prospérer: Les réalisations du plan décennal pour le développement économique et sociale du Congo belge 1949-1959 (Brussels: Imifi, 1959).

3 Philippe Boudon, Pessac de Le Corbusier 1927-1967: Étude socio-architecturale (Paris: Dunod, 1977). 
the immediate postwar years while an intensified agricultural production and the resulting distortion of the social structure of rural communities, which had occurred during the war years, also incited thousands of Africans to move to Kinshasa, Lubumbashi, Kisangani, and other urban centers. ${ }^{4}$ The sharply increasing growth rate of the African urban population quickly resulted in the emergence of bidonvilles popping up in the peripheries of the main urban centers. This forced colonial authorities to radically rethink their policies and strategies of urban governance. The provision of decent housing for Africans thus constituted one of the main objectives of the postwar Ten-Year Plan for the Social and Economic Development of the Belgian Congo which was launched in 1949. ${ }^{5}$ The colonial government undertook several initiatives in order to create sufficient housing facilities for the growing urban African population in a relatively short time frame. At the start of the Ten-Year Plan, it established the semi-governmental Office des Cités Indigènes (OCI) whose task was to build new so-called "Cités Indigènes" or "native towns" in the proximity of the main cities of the Belgian Congo and Ruanda-Urundi. ${ }^{6}$ In order to solve the managerial problems related to its decentralized structure, the OCI was already replaced in 1952 by the new semi-governmental Office des Cités Africaines (OCA) which was directed by a Brussels-based head office. ${ }^{7}$

As the Ten-Year Plan aimed at improving the well-being and welfare of both Europeans and Africans, it required an active socioeconomic state policy. It hence marked an important shift in housing policy in the Belgian colony. For the first time, the colonial government presented itself as the main provider of housing facilities for Africans, while previously colonial enterprises had taken

4 Between 1940 and 1945, Lubumbashi's African population knew its highest growth rate in the city's history (18\%) with a rise of approximately 26,000 to 65,000 African inhabitants. Bruce Fetter, The Creation of Elisabethville, 1910-1940 (Stanford: Hoover Institution Press, 1976), 173.

5 Ministère des Colonies, ed., Plan décennal pour le développement économique et social du Congo belge (Brussels: Les Editions de Visscher, 1949). For a brief discussion of the plan and its objectives, see Guy Vantemsche, "Le Plan Décennal et la modernisation du Congo belge (1949-1959)," in La mémoire du Congo: Le temps colonial, ed. Jean-Luc Vellut (Gent/Tervuren: Snoeck/MRAC, 2005).

6 For a genealogy of the OCI and the OCA, see Xavier Lejeune de Schiervel, Les nouvelles cités congolaises: L'architecture et le logement (Brussels: Académie Royale des Sciences coloniales, 1956), 38.

7 For a historical discussion of the OCA, see Bruno de Meulder, Kuvuanda Mbote: Een eeuw architectuur en stedenbouw in Kongo (Antwerpen: Hautekiet/deSingel, 2000), 185-251. Bruno De Meulder, "OCA (Office des Cités Africaines, 1952-1960) and the Urban Question in Central Africa,” accessed October 17, 2017, https://archnet.org/system/publications/contents/4922/ original/DPC1635.pdf?1384787195. 
up the largest responsibility in this domain of construction, building many workers' camps. ${ }^{8}$ The housing policy also shifted gradually towards the accommodation of African families rather than of single male laborers. Particular attention was given to the living standards in the African quarters, and initiatives were deployed to offer house ownership to the African dweller. This shift in policy is clearly reflected in the domain of action entrusted to the OCA which was assigned to organize the complete urbanization of new African quarters, from the design and implementation of the urban plans and dwellings to the attribution of the built houses to the African inhabitants. ${ }^{9}$ Moreover, the new "native towns" were not only to provide housing but also had to include all necessary public infrastructure, from roads and sewage systems to various facilities (administration, police, education, cult etc.). As Xavier Lejeune de Schiervel, the then director-general of the OCA, stated, this was a task that went far beyond a technocratic operation, for it was about providing "decent and hygienic accommodation in sufficient numbers" 10 which required an apt response in both quantitative and qualitative terms.

In its eight years' existence, the OCA built a significant number of African neighborhoods in cities such as Kinshasa, Lubumbashi, Kisangani, and Bujumbura, constructing a total of 40,000 new houses. Based on the model of the "neighborhood unit," the quarters were realized as fully-equipped satellite cities for approximately 30,000 inhabitants in the cities' peripheries. This large-scale enterprise testifies of the particular position of the OCA within the official sphere. Indeed, as it worked as a parastatale, the OCA profited from substantial financial means and was able to operate with a relative autonomy vis-àvis the colonial government. Moreover, Xavier Lejeune de Schiervel had attracted some prominent figures from the more progressive circles of Belgian architects and urban planners, giving them opportunities to create work on a scale that most of their colleagues, who worked in the colony at the time, could only dream of. ${ }^{11}$ As Bruno de Meulder has argued, the OCA actually succeeded in building cités that not only stood out as remarkable achievements in the field of housing in the Belgian colonial context, but that also surpassed - in scale, quality, and

8 See Bruno De Meulder, De Kampen van Kongo: Arbeid, kapitaal en rasveredeling in de koloniale planning (Amsterdam/Antwerpen: Meulenhoff/Kritak, 1996).

9 For the decree of 30 March 1952 on the creation of the OCA, see Lejeune De Schiervel, Les nouvelles cités congolaises, 49.

10 Lejeune de Schiervel, Les nouvelles cités congolaises, 10. All translations from French are by the authors.

11 Most of the designers working for the OCA were linked to or had been trained at La Cambre, an architectural school in Brussels that was considered as the "Bauhaus belge" at the time. 
coherence - most of the then current architectural production in the mother country itself. ${ }^{12}$ In the national and international architectural press of the time, the realizations of the OCA were highly praised (Fig. 3.1). Despite the social context and ambitions of the OCA projects, these neighborhoods remained very much "colonial projects": conceived as "satellite cities", at a significant distance from the existing urban centers, they were in tune with the segregationist logic that had characterized the urban planning policies in the Belgian Congo as well as elsewhere in sub-Saharan Africa since the 1910s and 1920s. ${ }^{13}$

\section{The Office des Cités Africaines in Lubumbashi}

From 1954 onwards, the OCA started to design the Ruashi neighborhood in Lubumbashi for a population of approximately 32,000 inhabitants. It was also involved in designing and constructing several public facilities, such as schools, churches, communal offices etc. in the other African neighborhoods of the city. While following the overall guidelines of the OCA's urban operations in other parts of Congo, the design and building process of the Ruashi neighborhood nevertheless was also influenced by the local particularities of Lubumbashi, the mining city situated in the southern province of Katanga and economic heart of the Belgian colony. ${ }^{14}$

Compared to other cities in Congo, Lubumbashi constitutes one of the clearest and most explicit illustrations of the binary colonial city, with clearly segregated areas for Europeans and Africans. ${ }^{15}$ Already in the city's first urban

12 De Meulder, Kuvuande Mbote, 189.

13 For a discussion of spatial segregation along racial lines in Belgian colonial urban planning, see Luce Beeckmans and Johan Lagae, "Kinshasa's Syndrome-planning in Historical Perspective: From Belgian Colonial Capital to Self-constructed Megalopolis," in Urban Planning in Sub-Saharan Africa: Colonial and Post-Colonial Planning Cultures, ed. Carlos Nunes Silva (Abingdon: Routledge, 2015), 201-224. For a concise but fundamental discussion of the segregationist logic of colonial urban planning in a comparative perspective, see Carl Nightingale, Segregation: A Global History of Divided Cities (Chicago: University of Chicago Press, 2012).

14 In this paper, we will refer to contemporary place names instead of colonial ones, thus using Lubumbashi instead of Elisabethville to refer to the city, and Commune Kamalondo instead of Cité Albert Ier for the first cité indigène or "native town" of the city. The place names of the other three "native towns" (Kenya, Katuba, and Ruashi) have not changed over time.

15 On segregation in Lubumbashi, see Johan Lagae, Sofie Boonen and Maarten Liefooghe, "Fissures dans le 'cordon sanitaire': Architecture hospitalière et ségrégation urbaine à Lubumbashi, 1920-1960," in Lubumbashi: Cent ans d'histoire, ed. Maurice Amuri MpalaLutebele (Paris: L'Harmattan, 2013). 


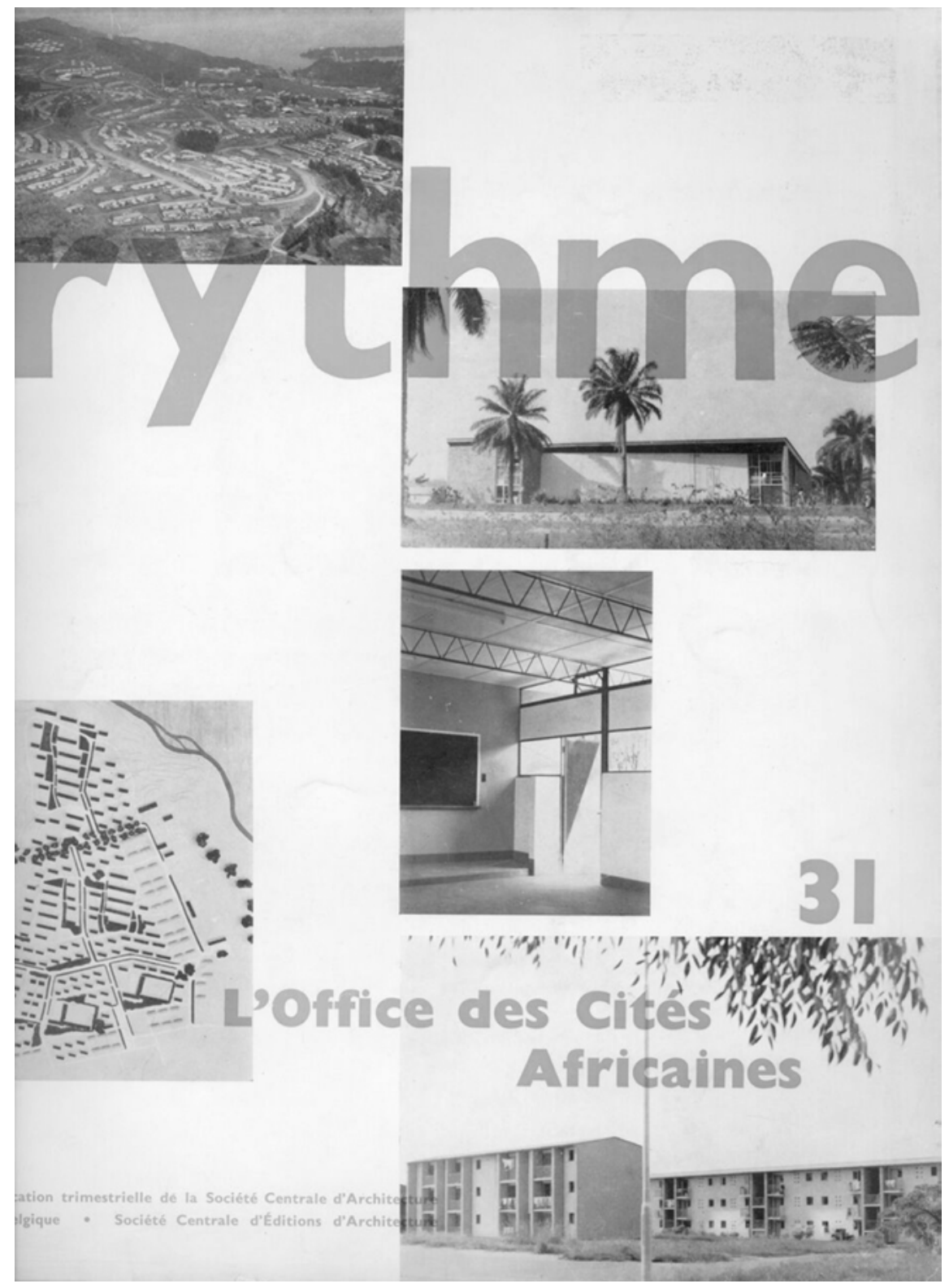

Figure 3.1: Cover of a theme issue of the Belgian architectural journal Rythme, devoted to the work of the Office des Cités Africaines, issue \#30, 1960.

Source: collection of Johan Lagae. 
plan, drawn up in 1911, such neat distinction was visible, with the settlement for Africans separated from the ville européenne by a 170-meter-wide buffer zone. This spatial division was to become much more explicit during the 1920s when the then governor-general Maurice Lippens requested that the first African settlement was to be razed because of what he described as a saleté repoussante ("disgusting filthiness"). ${ }^{16}$ A new cité indigéne Albert Ier, today Commune Kamalondo, was constructed at a larger distance of 700 meters which, according to contemporary sources, would prevent the transmission of malaria from the African to the European part of town. ${ }^{17}$

Already during the 1930s, the colonial government was confronted with a strong demographic pressure on the commune Kamalondo requiring an expansion of the neighborhoods for Africans. But it was only during the immediate postwar years that a project for a new "native town", the so-called commune Kenya, was realized. ${ }^{18}$ This, however, immediately proved to be insufficient as well, inciting the local policymakers to undertake new actions. The debates occurring within the colonial administration at the time help explain the peripheral situation of the Ruashi neighborhood: within the Comite Urbain, whose members represented the various power groups and communities within Lubumbashi's urban society, ${ }^{19}$ various locations for building new neighborhoods for Africans were discussed, taking into consideration two principles. First, it was considered necessary to break up the African community into small, manageable groups in an attempt to implement a "divide and rule" policy; and second, an encircling of the European city by African neighborhoods was to be avoided at all cost. While the creation of the commune Katuba, adjacent to the already existing cités of Kamalondo and Kenya, was in accordance with the second principle, the creation of the satellite city of

16 Lippens quoted in Ferdinand Grévisse, Le Centre Extra-Coutumier d'Elisabethville: Quelques aspects de la politique indigène du Haut-Katanga industriel (Brussels: Institut Royal Colonial Belge, 1950), 5 .

17 For the hygienic argument underlying this urban operation, see R. Hins, "L’Urbanisme au Katanga," Essor du Congo (1931), special edition on the occasion of the international exposition of Elisabethville, [s.p.].

18 A historical analysis of the development of this neigbourhood is provided by Simon de Nys-Ketels, "Koloniaal beleid en stedelijke ruimte in een Congolese stad: De wijk Kenya in Lubumbashi, Congo" (Master diss., Ghent University, 2011).

19 From the interwar period onwards, the urban planning of main urban centers as Kinshasa, Lubumbashi or Kisangani was mainly in hands of an "Urban Committee" (Comité Urbain), containing different services (e.g. the Public Health Service, Public Works Service, Services of the General Governor etc.) For more information on the "Urban Committee", see Crispin Mulumba, "Origines et Evolution des institutions communales et urbaines au Congo," Congo-Afrique 29 (1968). 
Ruashi, situated to the northeast of the existing city center, can be explained by the first (Fig. 3.2). ${ }^{20}$

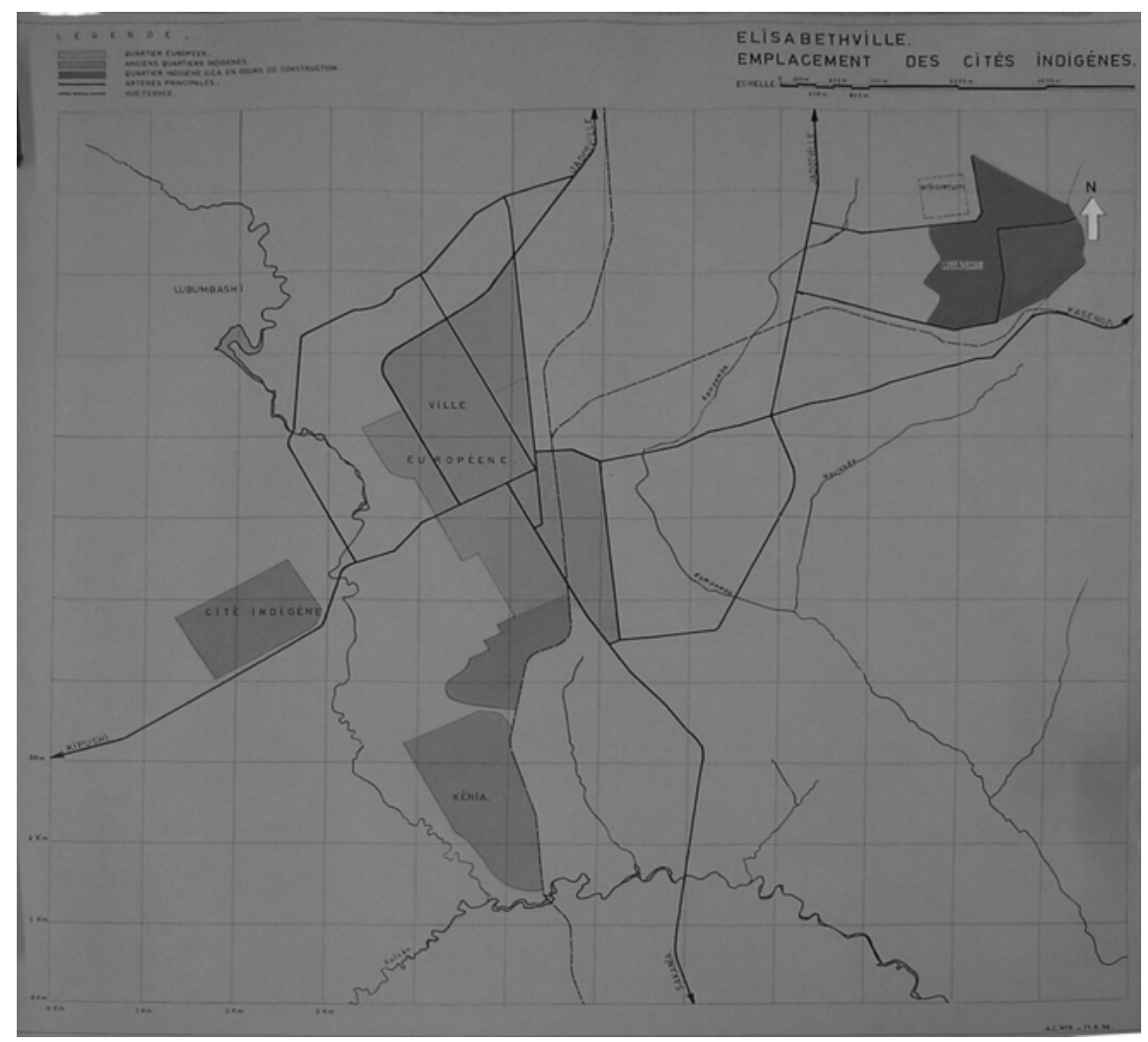

Figure 3.2: "Elisabethville. Emplacement des cites indigènes." Map showing the spatial organization of Lubumbashi with: in the middle the "European city," to the south, the two "native town" of Kamalondo and Kenya (the third one, Katuba, not existing then), to the west, along the road to Kipushi, the mining camp of the Union Minière (here indicated as a "cité indigène") and, to the north-east, the OCA neighborhood of Ruashi.

Source: Africa Archives, Ministry of Foreign Affairs, Brussels; Fund OCA, Courtesy Africa Archives.

Ruashi not only differed from Lubumbashi's other cités because of its oppositional geographical location, but it also had, as we shall discuss below, a spatial layout which contrasted with the grid-pattern structuring the other cités of

20 GG.20.400. Congo Belge. Nouveaux emplacements - Urbanisme, 1945-1949, Africa Archives Brussels (hereafter AA). 
Kamalondo, Kenya and Katuba. In terms of housing, the Katuba neighborhood was based on the so-called Système Grévisse, which encouraged the African population to participate in the construction of their own residences, albeit under strict supervision and following a predefined list of restrictions and obligations on technical issues. ${ }^{21}$ In the Système Grévisse, the foundations of the houses were constructed by the colonial administration itself in order to keep control of the precise dimensions and the exact positioning of the house on the parcel. The main body of the house was then to be erected by the future inhabitants themselves, with materials provided by the government at favorable prices (Fig. 3.3). This construction method allowed the bypassing of qualified construction firms and promoted the use of prefabricated mass-produced elements, such as windows, doors, and roof elements, reducing the building costs significantly.

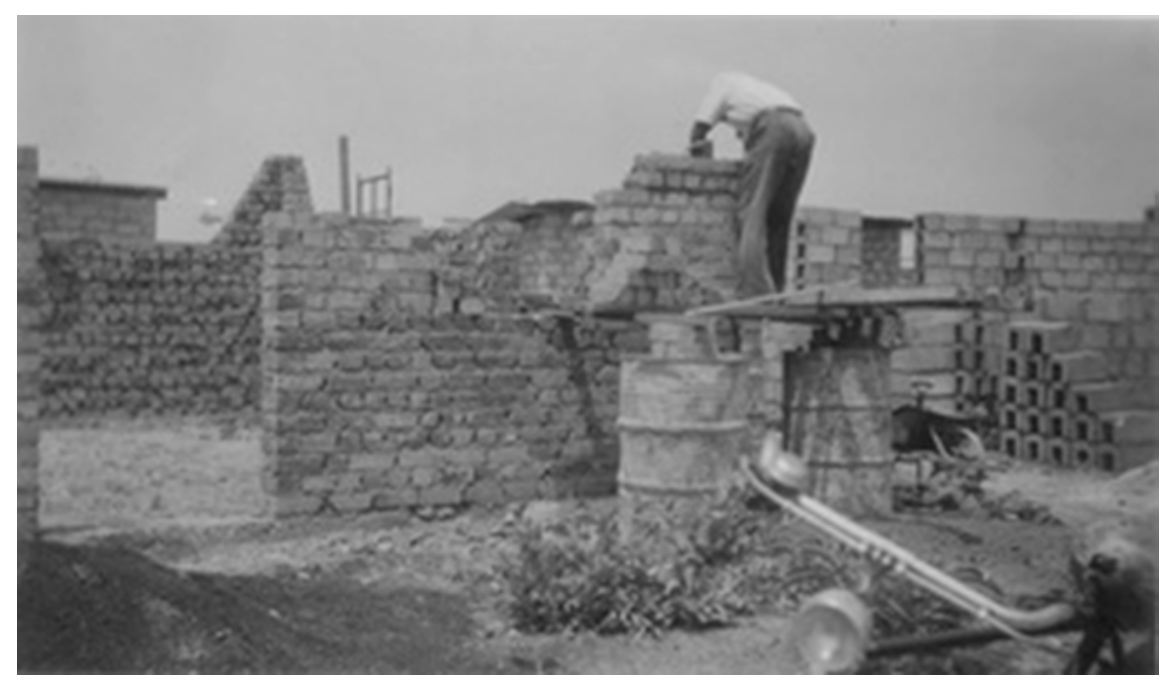

Figure 3.3: Building with the Système Grévisse in Lubumbashi.

Source: Archives of the Soeurs de la Charité, Gent, file A 76-CON Lubumbashi.

For Ferdinand Grévisse, the then district commissioner and fervent promoter of this method, its real importance did not reside in the technical aspects or in the architectural quality of the houses alone. He rather accentuated its social

21 The Système Grévisse was called after Ferdinand Grévisse, the then district commissioner, who published a study on the "native towns" of Lubumbashi: Grévisse, Le Centre ExtraCoutumier d'Elisabethville. 
dimensions. By encouraging the future inhabitants to participate in the construction and, in addition, giving them the possibility to become owners of their residence, the Système Grévisse, he argued, would introduce order and stability in the life of the African urbanite, and, moreover, anchor him more firmly to the colonial project as "he would no longer be the simple proletarian who is condemned to an absolute dependency on his employer." 22 In that sense, this housing policy was (very) similar to the promotion of individual home ownership that the Catholic party and related associations were developing at the time in Belgium to turn the laborer into a docile member of Belgian society by stimulating him to buy and build his own house. ${ }^{23}$

Already in 1950, Grévisse argued that, given the immediate success of his approach (at the time over a thousand houses had been built according to the Système Grévisse), it provided the ultimate solution to Lubumbashi's housing crisis. Yet, the construction method was also harshly criticized because of the poor technical quality of houses built by laymen, the underestimation of real costs as well as the minimal surface that left little flexibility for spatially organizing the house. Some of the more acerbic critiques were, not surprisingly, formulated by those who were in favor of the OCA approach to the housing problem, such as G. Mosmans. ${ }^{24}$ Lubumbashi quickly became the stage of conflicts and tensions between the promoters of both housing schemes which presented fundamentally divergent positions regarding the role of the state in responding to the housing crisis. While the Système Grévisse granted a large initiative to the future African inhabitants themselves, the OCA schemes favored a top-down approach allowing close monitoring of each step in the planning and building process.

\section{Implementing the Model}

The OCA cités were based on the urban concept of the "neighborhood unit", a particular kind of spatial organization of settlements which gained a strong currency in circles of modernist architects and planners in the immediate postwar

22 Grévisse, Le Centre Extra-Coutumier d'Elisabethville, 204.

23 This approach was institutionalized by the notorious law De Taeye, that formed a major cornerstone of postwar housing policies in Belgium, see Tom Avermaete et al., eds., Wonen in Welvaart: woningbouw en wooncultuur in Vlaanderen 1948-1973 (Antwerpen: deSingel, 2006).

24 For a contemporary comparison between the two approaches, see Georges Mosmans, “Elisabethville - Méthodes Grévisse et OCA, September 18, 1955," in file 566, portfolio 96, Inventory OCA dossiers, AA. 
years. ${ }^{25}$ It was premised on the creation of a qualitative urban environment which required a spatial organization that took into account the human scale as well as the provision of community enhancing facilities and public spaces. Ruashi was originally conceived to house approximately 32,000 inhabitants, with the whole neighborhood being divided into five autonomous sub-quarters of each around 6,000 inhabitants, spatially separated from each other by large roads (Fig. 3.4a, b). While this sub-structuring had its roots in some of the modernist planning principles of the time, it also echoed the preference of Lubumbashi's Comité Urbain for splitting the growing African urban population into separated communities in order to better control and discipline it.

In line with the original concept, however, the "neighborhood unit" was used by the OCA on the basis of social grounds which are clearly described in a late 1963 article written by the architect and urban planner Ernest Scaillon, a prominent former member of OCA's main architectural section. In contrast to the earlier modernist urban planning principle of the functionalist city, which aimed at a clear separation of the different functions of life (dwelling, work, transportation, recreation), Scaillon presented the advantage of the "neighborhood unit" concept as its capacity to enable an interlocking of various urban functions, thus creating a coherent and harmonious living environment which would stimulate a sense of community and belonging. ${ }^{26}$ To that end, not only housing but also a variety of public facilities needed to be provided, both on the scale of the whole neighborhood and on that of its constituent subquarters (Fig. 3.5). The Ruashi neighborhood was thus organized around a communal center, comprising the communal administrative center, a tribunal, a police station, a main market, and a church, while the sub-quarters had their own centers with, among others, a local school, medical facility, market and/or shops, a sports field, a church and a foyer social, where Congolese women could be trained to become "respectable and devoted" housewives (Fig. 3.6). ${ }^{27}$ In their

25 The concept of the "neighborhood unit", which has its origin in US urban planning practices of the 1920s, became a key concept in discussions on modern urban planning in Europe in the late 1940s and was explicitly discussed in the 6th Congrès International d'Architecture Moderne (CIAM), held in Bridgewater in 1947. For an elaborate discussion, see Auke Van der Woud, CIAM: Housing Town Planning (Delft: Delft University Press, 1983). Eric Mumford, The CIAM Discourse on Urbanism, 1928-1960 (Cambridge, Mass.: MIT Press, 2000).

26 Ernest Scaillon, “La rénovation urbaine et l'unité de voisinage,” Rythme 37 (1963).

27 On the role of the foyers sociaux as instruments to create "respectable, devoted housewives", see for instance Nancy Rose Hunt, "Domesticity and Colonialism in Belgian Africa: Usumbura’s Foyer Social, 1946-1960,” Signs 15 (1990). 
spatial layout, the OCA neighborhoods differed significantly from the grid-pattern, commonly used as the template of the cité indigène because of considerations of efficiency and governmentality. In the OCA neighborhoods, a more diverse and visually stimulating landscape was created via an irregular pattern of main roads and dead-end streets, punctuated by open spaces creating gravitational points in the overall urban tissue, with rows of houses oriented in such a way that they took into consideration climatic conditions (protecting against the sun, while opening

(a)

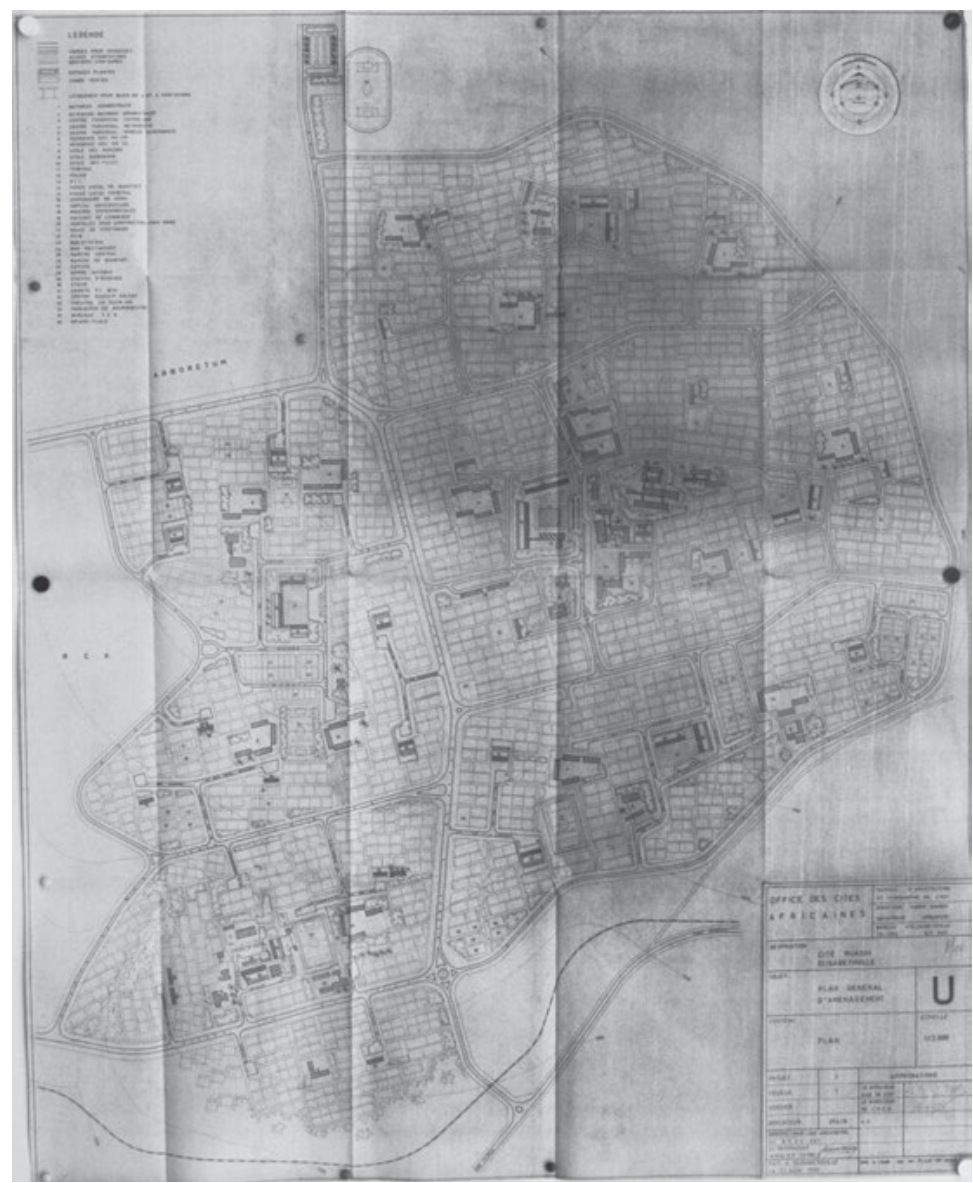

Figure 3.4a: "Ruashi/Elisabethville. Plan general d'aménagement." Overall masterplan for the Ruashi-neighborhood, Office des Cités Africaines, 1959.

Source: Africa Archives, Ministry of Foreign Affairs, Brussels; Fund OCA, Courtesy AA. 
(b)

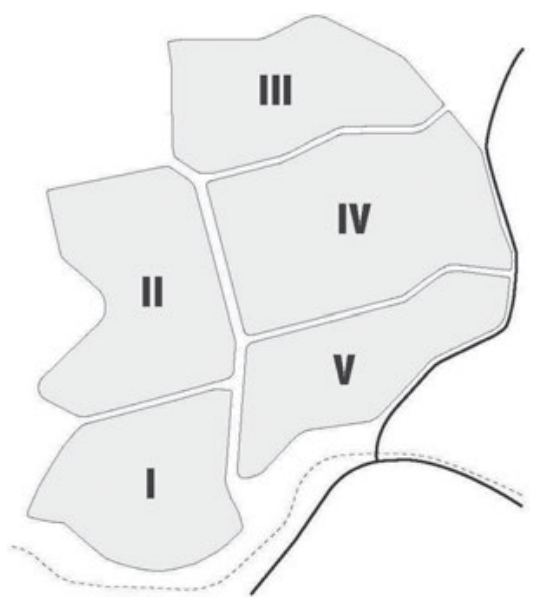

Figure 3.4b: Scheme of the division of the Ruashi neighborhood, designed for around 32,000 inhabitants, distributed into five sections of about 6,000 inhabitants each. Source: scheme drawn by Céline Fenaux, based on archival material, 2010.

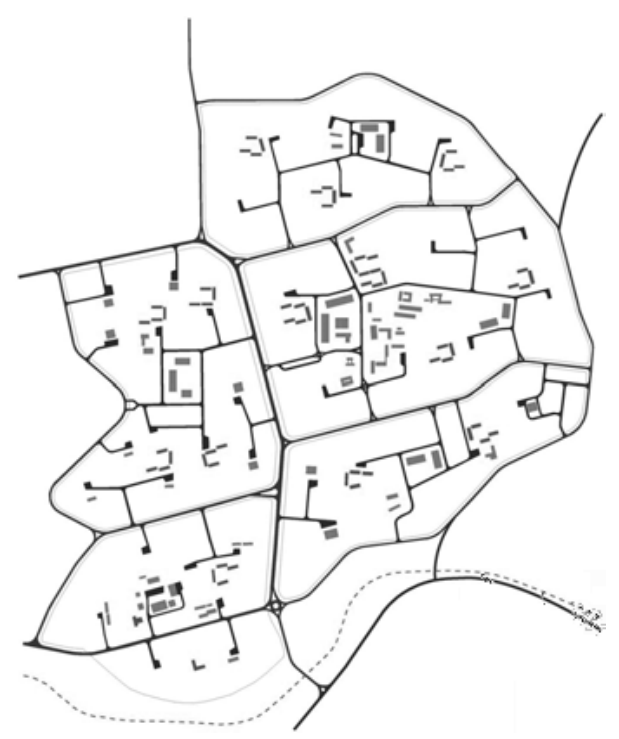

Figure 3.5: Fragment of the plan of the Ruashi neighborhood, indicating the public facilities and the main road infrastructure with the characteristic dead end streets. Source: scheme drawn by Céline Fenaux, based on archival material, 2010. 


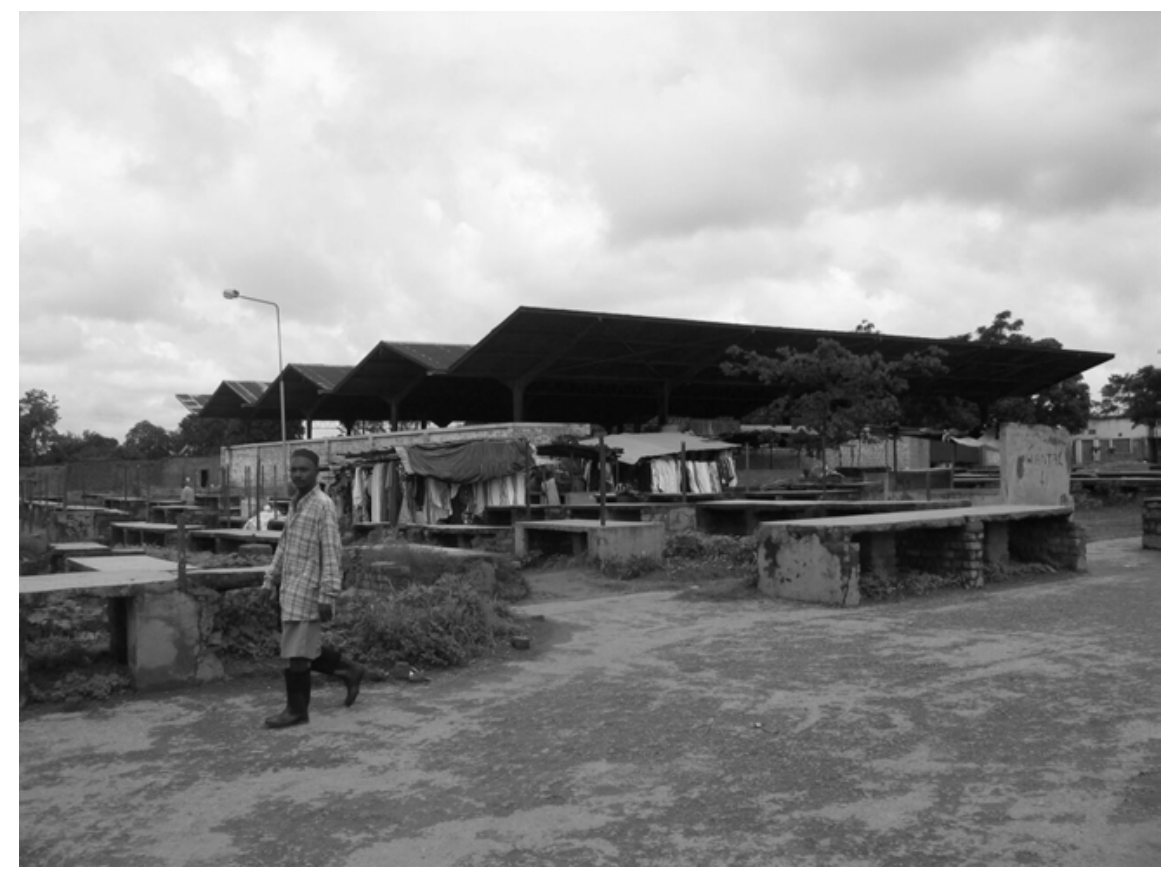

Figure 3.6: The central market of Ruashi, designed by OCA architect J. Castel-Branco, ca. 1959. Source: photograph by Johan Lagae, 2006.

up to dominant breezes) as well as the characteristics of the site, such as hydrography and topography (Fig. 3.4a). ${ }^{28}$

Designing and building the Ruashi neighborhood proved a complex affair, however, with tensions between the central and local administration rising throughout the process. While Xavier Lejeune de Schiervel, the head of the OCA, tried to enforce general design guidelines to be applied all over the Congolese territory, the head of the OCA office in Lubumbashi, C. Porta, accused his colleagues in the mother country of being totally ignorant of local realities. ${ }^{29}$ Major discussions occurred around the issue of density as well as on the introduction

28 In this respect, the OCA planners seemed to be also drawing lessons from the layout of the 1920s "garden city" neighborhoods in the periphery of Brussels, such as Le Logis Floréal which had gained international acclaim in its day. The low density of this "garden-city" model was countered by applying terraced houses and, if possible, maisons à étage, rather than single houses surrounded by individual gardens.

29 File 568, portfolio 96; file 569, portfolio 96; file 3012, portfolio 749, Inventory OCA dossiers, AA. 
of new housing typologies, such as the maison à étage, a solution Porta feared would not be popular among Africans. The main office in Brussels, in turn, critiqued the local designers in Lubumbashi of treating the different sub-quarters as separate entities, fearing this would result in a loss of overall coherence. ${ }^{30}$ Tellingly, when the first quarter was almost finished, the fifth was still in the phase of conception.

\section{A Failed Housing Policy?}

In a timeframe of eight years, OCA succeeded in constructing 40,000 houses, an achievement that was celebrated in colonial propaganda as an adequate response to the housing crisis. In 1957, official sources had reported that the OCA "builds one house every 15 minutes." 31 This substantial effort, however, did by far not match the actual needs. Ruashi was no exception, as in quantitative terms the number of houses planned was far too limited to tackle Lubumbashi's exploding population. ${ }^{32}$ Moreover, in 1960 - the year that Congo gained its independence the Ruashi neighborhood was still far from complete. Of the five sub-quarters initially planned, only the first was completely realized and two others were only partially built, while of the remaining two even the road network was not yet fully completed (Fig. 3.7). ${ }^{33}$ Because of financial constraints, moreover, the public facilities were the first elements of the plan to be eliminated during construction.

Given the shortage of accommodation for Africans, it is remarkable that many of the OCA houses in Ruashi remained unoccupied, just as was the case in OCA neighborhoods in other cities. ${ }^{34}$ The increase of building costs which

30 See for instance the correspondence between the Manager-Administrator of the OCA and the director in Lubumbashi. "Cité Ruashi à Elisabethville. Quartiers 3 et 4, 16 april 1957,” File 3012, portfolio 749, inventory OCA dossiers, AA.

31 Statement from the 1957 annual report of OCA, mentioned in Bruno de Meulder, Kuvuande Mbote, 199.

32 In 1958, the city's population was 168,775 inhabitants, a number which almost doubled by 1970 to 318,000. Léon de Saint-Moulin, Villes et organisation de l'espace en République Démocratique du Congo (Paris: L'Harmattan, 2010), 127. For a more elaborate survey of the evolution of Lubumbashi's population, see Jean-Claude Bruneau and Marc Pain, eds., Atlas de Lubumbashi (Nanterre: Université de Paris X, 1990).

33 Céline Fenaux executed a detailed mapping of the existing physical landscape of Ruashi during a fieldwork trip in January-February 2010.

34 In 1955, the deplorable results were reported by presenting percentages of unoccupied houses in the OCA quarters of Kinshasa (36\%), Stanleyville (40\%), Bukavu (64\%) and Usumbura (55\%). Georges Moulaert, Comité du Congres Colonial National. Notes concernant le Rapport de la 


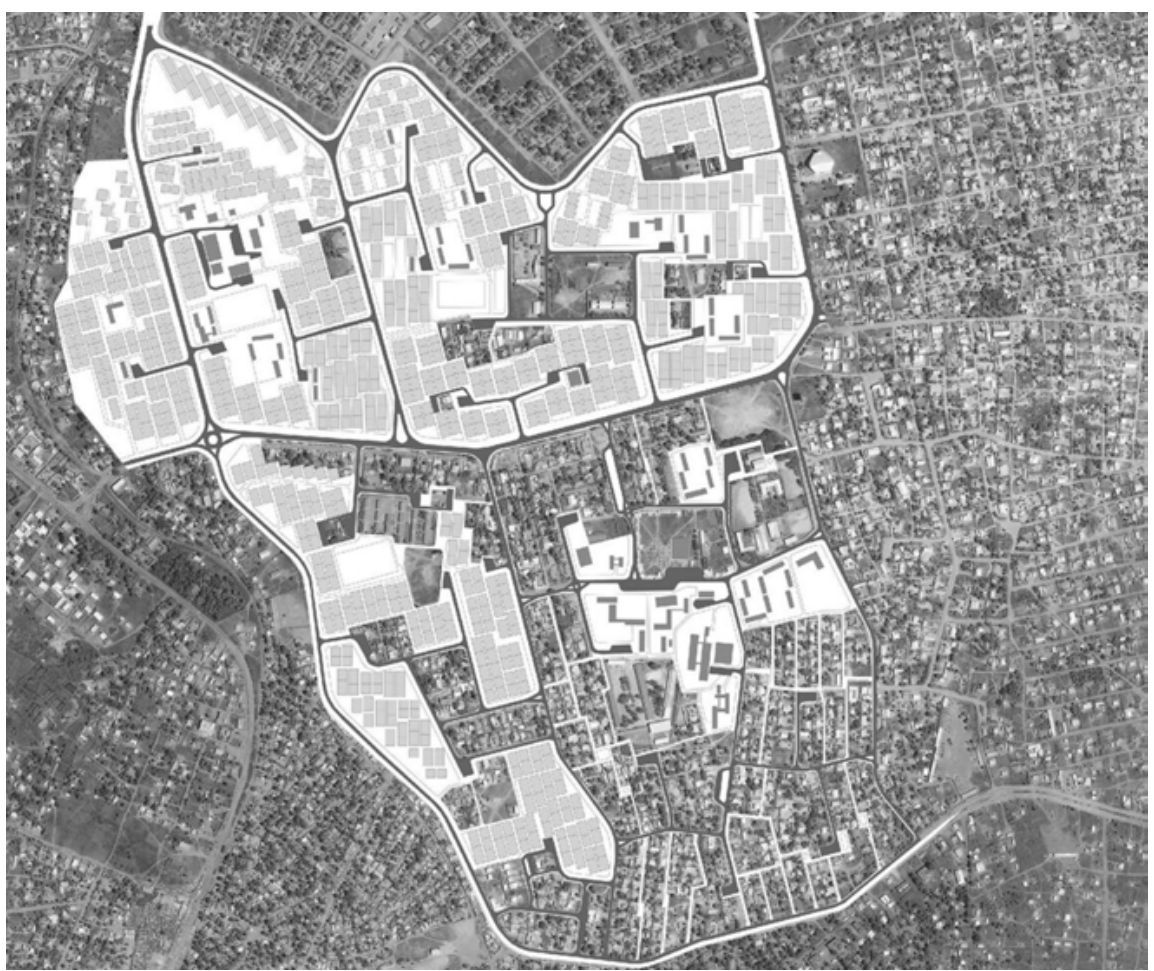

Figure 3.7: Aerial photograph of the Ruashi neighborhood anno 2010, with an overlay of those fragments of the original masterplan, indicating those parts which were executed according to the initial design.

Source: montage by Céline Fenaux based on fieldwork observations, 2010.

had resulted from the use of durable materials, from the elaborate architectural design and from the provision of up-to-date domestic equipment, such as electricity or tap water, made the prices for which the houses could be sold or rented out too high for the majority of the African population and even for the emerging class of so-called "évolués". In his 1958 critical analysis of the urban conditions in Central African cities, geographer Jacques Denis provided another explanation for the limited success of the OCA housing policy: even if the OCA technicians had found "laudable solutions" in terms of urban planning, architecture, and funding, and even if their choice of adopting European standards

Commission pour l'étude de l'habitation du Congolais (July 1955). File 3012, portfolio 749, inventory OCA dossiers, AA. 
in the domain of urban dwellings was "justified", they "hadn't paid enough attention to social and psychological issues" and should have prepared the public opinion for what was, in fact, a "revolution in African housing" in order to "soften its brutality."35

The OCA nevertheless had made a genuine effort of researching the dwelling needs and practices of its future inhabitants. Some of its housing types, for instance, were explicitly designed to allow inhabitants to respond to their evolving living conditions and dynamic patterns of occupancy and use. Not only did the OCA provide some types of mixed program dwellings (residence/commerce), it also elaborated the so-called "expanding house" or la maison extensible, a house that could grow in relation to the changing needs of the family (Fig. 3.8a, b). ${ }^{36}$ This two-story house type was conceived so that it could accommodate a variety of scenarios of cohabitation, ranging from a family with up to eight children to a couple without children that could rent out rooms on the second story to five extra residents with neither having to alter fundamentally the internal structure of the house nor having to extend it with additional parts. The design allowed a response to such different scenarios and arrangements of living together with little to no modifications of the house itself in order to make sure that the overall architectural landscape of the OCA neighborhood would not be hampered in the future by the emergence of informal constructions. The development of the type of the maison extensible was, in other words, as much a question of aesthetics as it was of social and cultural sensitivity towards local dwelling practices.

Before proceeding to the actual construction of houses in Ruashi, different types were first tested out on an "experimental site" in the middle of the existing African quarter Kamalondo in order to grasp the reactions of the targeted inhabitants (Fig. 3.9). ${ }^{37}$ While this demonstrated the unpopularity, particularly of the terraced and two-story housing types, all designs were nevertheless applied in Ruashi. The local government also undertook several initiatives to "educate" the African population in new dwelling practices, such as the publication of an informative brochure on the maison modèle, creating a fully furnished maison témoin that could be visited, and organizing a series of competitions honoring the most beautiful house/garden/interior of the cité. Deeply rooted in the paternalistic rationale underlying postwar colonial policies

35 Jacques Denis, Le phénomène urbain en Afrique Centrale (Namur: s.d. [1958]), 307.

36 Lejeune de Schiervel, Les nouvelles cités congolaises, 109-112.

37 Xavier Lejeune de Schiervel in a report sent to Emile Henvaux. "Rapport sur la direction d'Elisabethville," April 6, 1954, in: Inventory OCA dossiers, portfolio 96, file 566, AA. See also “Chantier expérimental au centre," August 5, 1954, file 1359, portfolio 270; file 3012, portfolio 749, inventory OCA dossiers, AA. 
(a)

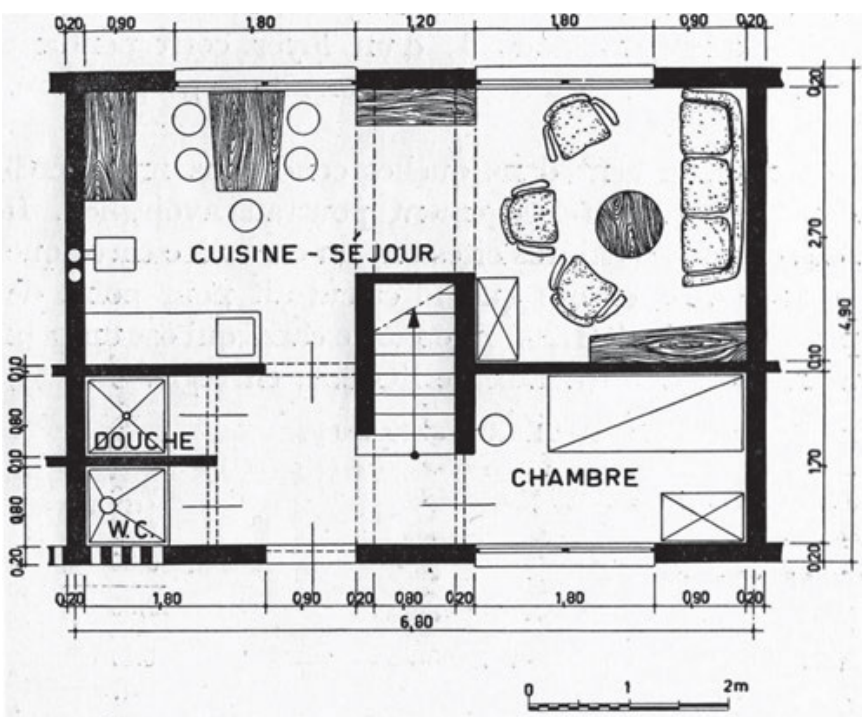

Plan 22. - Maison à un étagə, à occupation variable. Rez-de-chaussée.

Figure 3.8a: Plan of the ground floor of the maison extensible-type, with living unit, kitchen, one bedroom and sanitary facilities.

Source: Lejeune de Schiervel, Xavier. Les nouvelles cités congolaises: L'architecture et le logement, 1956, 111.

(b)

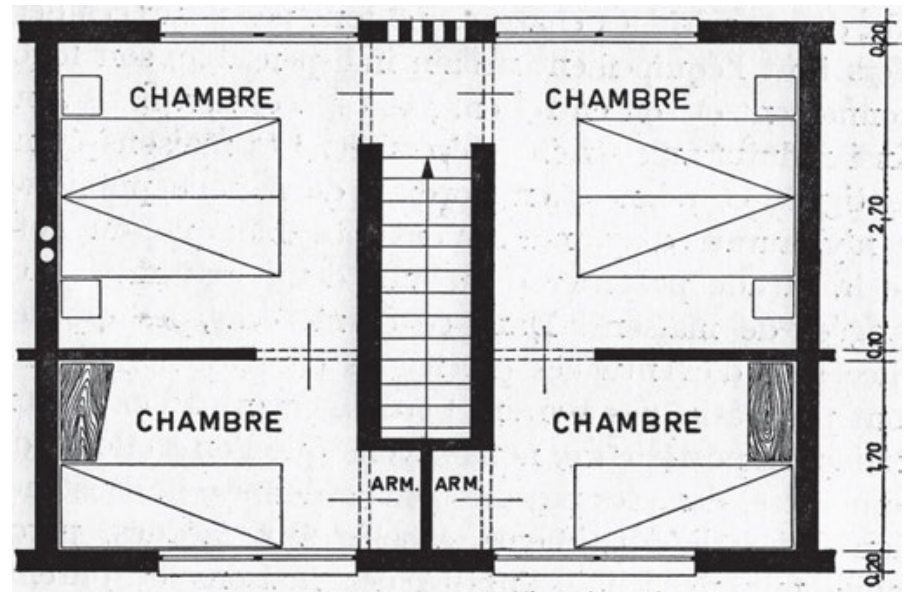

PLAN 21. - Maison à un étage, à occupation variable. Étage.

Figure 3.8b: Plan of the first floor of the maison extensible-type with two double bedrooms and two single bedrooms.

Source: Lejeune de Schiervel, Xavier. Les nouvelles cités congolaises: L'architecture et le logement, 1956, 110. 


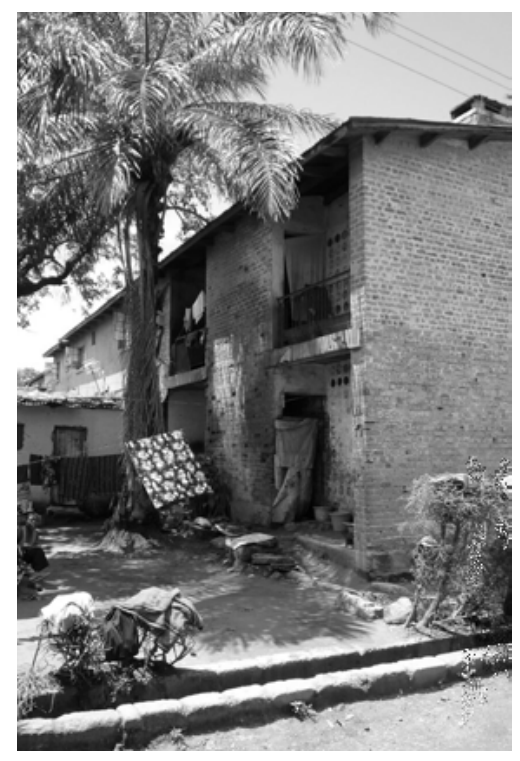

Figure 3.9: Two-story OCA houses erected in the "experimental site" in the Kamalondo neighborhood, situation anno 2010. Source: photograph by Céline Fenaux, 2010.

in the Belgian Congo, such initiatives were also in tune with then current practices in the mother country that sought to educate the Belgian housewife in "modern living" via a variety of popularizing media targeting a broad audience (exhibitions of model houses and interiors, lectures, publications in newspapers and women's magazines etc.). ${ }^{38}$

A particular effort was made on behalf of the OCA to promote the maison $\grave{a}$ étage, as this was an essential instrument for reaching a sufficient density in the Ruashi neighborhood. Despite several initiatives, including conferences in the foyers sociaux that targeted a female Congolese audience, an exhibition, and special lectures on the topic in schools, ${ }^{39}$ this particular housing type proved extremely unpopular because "Congolese felt cold on the first floor." ${ }^{40}$ The number

38 For a discussion of such initiatives in a metropolitan context, see Fredie Floré and Emiel de Kooning, "Post-war Model Homes: Introduction,” Journal of Architecture 4 (2004).

39 Files 3012 and 3019, portfolio 749, inventory OCA dossiers, AA.

40 Letter of the director of the OCA in Lubumbashi to the central office of OCA in Brussels. "Construction de logements," 10 August 1959, file 419, portfolio 70, inventory OCA dossiers, AA. The fact that the housing designs followed the guidelines of "tropical modernism" and thus included architectonic solutions for enabling cross-ventilation was not appreciated by Congolese inhabitants as it created in their opinion a feeling of an uncomfortable draught. Interview with Jan Maes, a former OCA architect, April 1996. 
of maisons à étage standing vacant after realization reached disturbing numbers by the end of the 1950s, leading local OCA officials to start negotiations with local enterprises to house their employees in these dwellings - an attempt that would, however, remain without much result. ${ }^{41}$ If the housing policy of the OCA failed in a number of aspects, this was in large part due to the unwillingness of the Brussels-based OCA officials, architects, and planners who promoted general solutions to the problem of housing shortage based on abstract ideas of rationality and cost-efficiency rather than adapting to local specificities of which they were constantly informed by the local OCA branches operating on the ground. ${ }^{42}$

\section{A Transformed Urban Landscape}

The OCA houses were not merely intended to provide shelter for the booming African population in Congo's major urban centers. They were also a major element in a broader project of social engineering aimed at the "emancipation" of the African household that was defined in terms of a nuclear family. With the exception of the maison extensible, that in fact only formed a marginal typology in the OCA plans, the modest one-family dwelling typical in Belgium constituted the main template. Moreover, the kitchen was planned inside the house in order to "integrate" the Congolese woman more in the family life (Fig. 3.10). It would, as one contemporary observer put it, allow to have her children around her while cooking and stimulate her to eat together with the chef de la famille. ${ }^{43}$ As such, the design of the generic OCA house was in tune with the policy of educating the Congolese housewife in the foyer social in order to turn her into a "devoted spouse."

It soon became clear, however, that this attempt at interiorizing the daily life was not very successful. The majority of inhabitants of the OCA neighborhood

41 An in-depth discussion of the measures to counter the fact that many OCA houses remained vacant is provided in Fenaux, L'Office des Cités Africaines, 217-221. This analysis is based on various files of the OCA fund in the AA (portfolio 749, files 3012, 2019; portfolio 70: 419; portfolio 96: 567).

42 It is tempting to draw a distinction here with the housing program in Casablanca run by the architect and planner Michel Ecochard around the same time, a program that seemed much more embedded in interdisciplinary research of local dwelling habits. See for instance Tom Avermaete, "Framing the Afropolis: Michel Ecochard and the African City for the Greatest Number," Oase 82 (2010).

43 Fernand Peigneux, "De l'habitation," Bulletin de l'Union des Femmes Coloniales 1 (1954). Peigneux also pointed out reasons for cost-efficiency. 


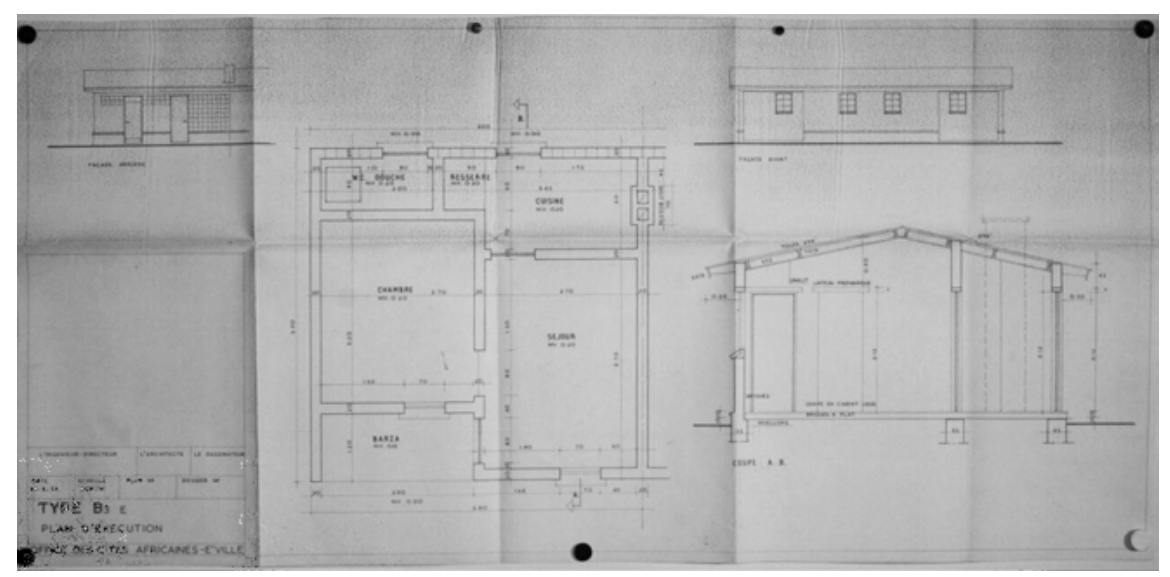

Figure 3.10: Architectural drawing of a single-story OCA house for Elisabethville/Lubumbashi, type B, 1954.

Source: Africa Archives, Ministry of Foreign Affairs, Brussels; Fund OCA, Courtesy AA.

continued to cook outside, in the open air, as this was an intrinsic part of African social life. On photographs commissioned by the OCA in the late 1950s, one can also see the first traces of an informal appropriation of the public spaces. In front of the two-story housing types with commercial shops on the ground floor, we actually see a number of women selling food on improvised stalls, while in other photographs some graffiti-like writings already appear on the colorful façades (Fig. 3.11a, 11b). ${ }^{44}$ When, after independence, a new flux of migrants from the rural areas arrived in urban centers like Lubumbashi, the nuclear families living in the OCA houses were gradually being replaced or reshaped as extended families, defined by complex social relationships based on kinship and ethnicity. Hence, inhabitants were forced to adapt and transform the hardware of most of the houses and also started appropriating the open spaces of the neighborhood. Today, Ruashi presents a profoundly altered urban landscape, testifying of a long process of appropriation, adaptation, and transformation, a phenomenon that is also discernible in the OCA neighborhoods in other Congolese cities, in Kinshasa in particular. ${ }^{45}$

44 These photographs are kept in the form of color slides in the OCA fund, AA.

45 For Kinshasa, see Bruno de Meulder and Marie-Françoise Plissart, "Kinshasa, the Hereafter of Modern Architecture," in Back from Utopia: The Challenge of the Modern Movement, ed. HubertJan Henket and Hilde Heynen (Rotterdam: 010 Publishers, 2002). Dirk Pauwels, "Souvenirs of Urbanism,” in Brakin: Brazzaville - Kinshasa: Visualizing the Visible, ed. Wim Cuyvers (Baden: Lars Müller Publishers, 2006). For Kisangani, see Sally Lierman, "Office des Cités Africaines in 
(a)

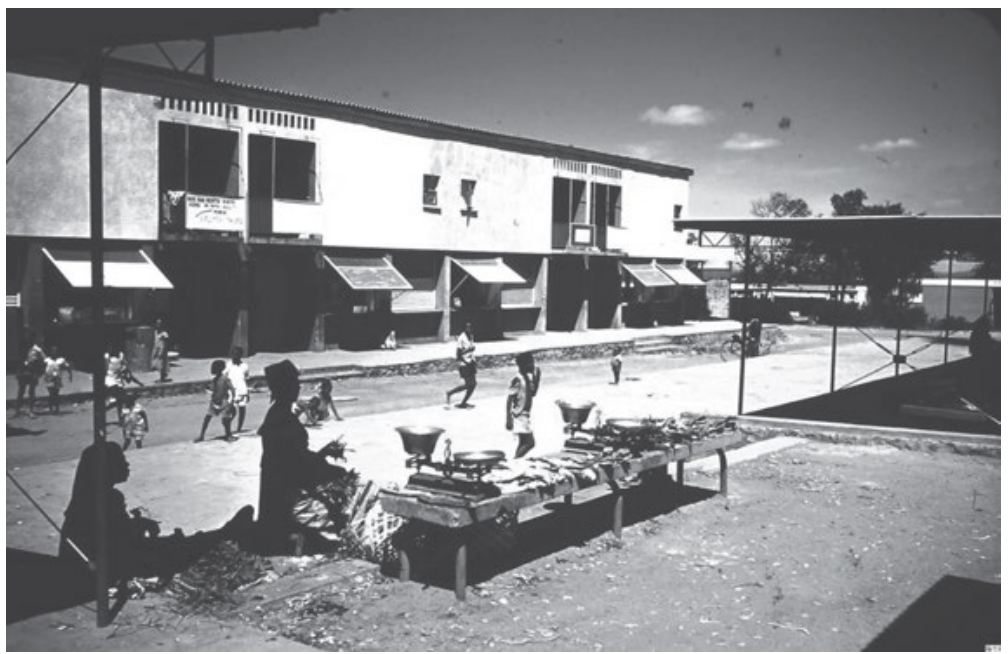

Figure 3.11a: Two-story housing with shops for commercial activities on the ground floor. Notice the informal infrastructure for selling food in the front, situation late 1950 s.

Source: contemporary original color slide, AA, Ministry of Foreign Affairs, Brussels; Fund OCA, Courtesy AA.

(b)

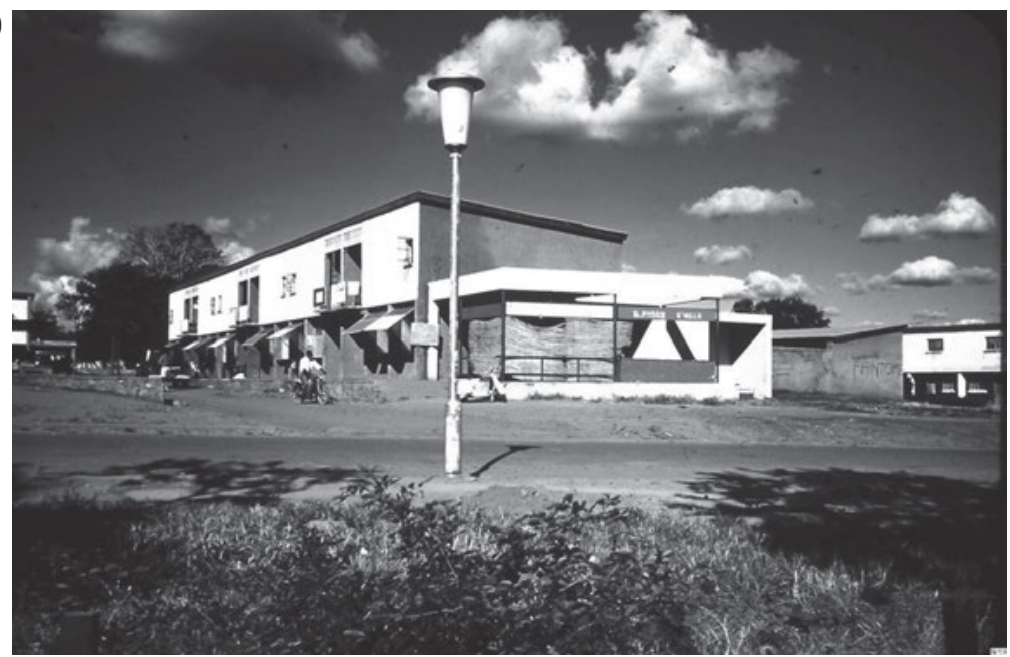

Figure 3.11b: Two-story housing with shops for commercial activities on the ground floor and some storage facilities in the back. Notice the graffiti-like inscription fantôme ("ghost") on the side façade on the right, situation late 1950s.

Source: contemporary original color slide, AA, Ministry of Foreign Affairs, Brussels; Fund OCA, Courtesy, AA. 
A detailed mapping of the transformed landscape of Ruashi was conducted during fieldwork in early 2010, documenting the altered built environments in photographs and drawings, and conducting interviews to gain an understanding of these transformations. ${ }^{46}$ While several interviewees pointed out the orderly and clean character of the neighborhood when they first arrived, often decades ago, Ruashi's urban landscape now commonly evokes a strong sense of disorder and bricolage: "Ruashi no longer is clean, as it once used to be." 47 The mapping demonstrated a number of shared strategies of transformation, the most striking of which consists of enclosures that were put up around the houses and have significantly altered part of the streetscape of the OCA cité. (Fig. 3.12). Serving as a

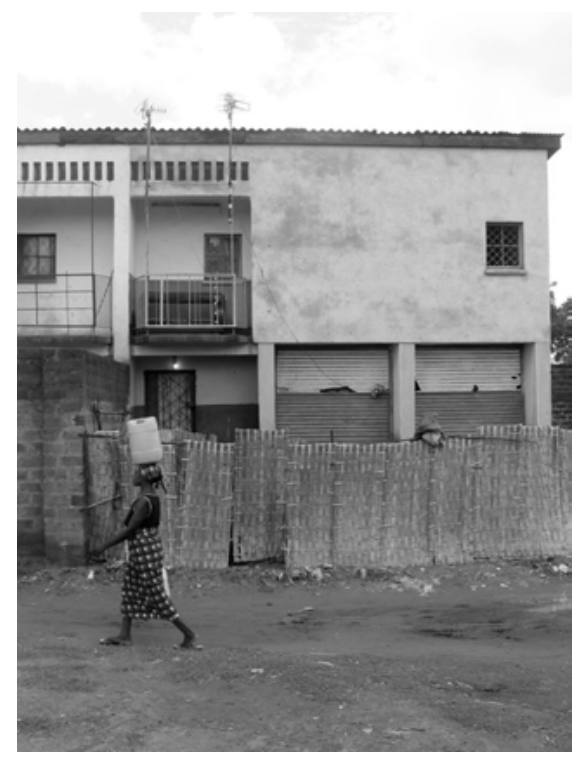

Figure 3.12: Enclosures in various materials in front of two-story houses with commercial shops on the ground floor, situation anno 2006.

Source: photograph by Johan Lagae, 2006.

Kisangani: Een stedenbouwkundig onderzoek naar genese en toe-eigening van een woonwijk uit de jaren 1950 in Afrika” (Master diss., Ghent University, 2011).

46 During January and February 2010, a total of 35 interviews was conducted in Ruashi by Céline Fenaux in collaboration with Serge Songa Songa Mitwa, an assistant from the History Department of the University of Lubumbashi. Interviewees were selected in such a way as to obtain a varied sample of inhabitants by taking into consideration a distribution in space (interviewees came from the different sub-quarters), age, profession, and gender.

47 Madame M., a Congolese woman living in quartier 1, interviewed in Lubumbashi on 31 January 2010. 
protective shield, such enclosures emerged mainly in the 1980s, an era of growing insecurity that has even reshaped Lubumbashi's city center into what now seems a completely privatized environment or a ville bunkerisée. Yet, such walls are never absolute boundaries but rather constitute liminal spaces allowing for different forms of negotiation and encounter. ${ }^{48}$ Fieldwork demonstrated that the practice of constructing a small shop adjacent to the house is widespread, often in the form of a freestanding little, temporary shack, thus altering drastically the original structure of the OCA neighborhood unit model in which commercial activity was limited to the main market near the communal center and the submarkets on the level of each sub-quarter. Sometimes, the main structure of the OCA house itself has been changed, for instance, by filling in the so-called barza, a small outdoor space. Echoing the outdoor room of vernacular African houses where it constituted an important social space, the barza in the OCA houses were too small to be of any real use and have hence, not surprisingly, been adapted and often even extended with a complete extra room at the front of the house, accommodating sometimes complex arrangements of living together (Fig. 3.13). Such front rooms can serve commercial purposes with a semi-public character during the day, while at night they become part of the house again and serve as an extra bedroom. Another recurrent practice of transforming OCA houses consists of adding constructions to the back of the house, creating extra bedrooms or providing for better sanitary facilities. Apart from adding habitable space, such additions also fundamentally alter the status of the back garden, which often becomes an outdoor room that serves as the real heart of the home where people cook, wash, clean, play, rest, and socialize (Fig. 3.14).

\section{A Pessac in Congo?}

What do such transformations mean when reflecting on OCA's legacy in Congo? In a provocative analysis, Bruno de Meulder argued that the OCA cités quickly became seen as a "symbol of oppression" after independence, as they were associated with the paternalistic attitude of Belgian colonial policy and were thus infrastructures par excellence on which the discontent with the "petty apartheid" regime in Congolese cities was projected. In his opinion, it was no coincidence

48 For a discussion of this phenomenon, see Johan Lagae, Sofie Boonen and Sam Lanckriet, "Navigating 'Off Radar': The Heritage of Liminal Spaces in the City Center of Colonial/ Postcolonial Lubumbashi, DR Congo," in Things Don't Really Exist Until You Give Them A Name: Unpacking Urban Heritage, eds. Rachel Lee et al. (Dar es Salaam: Mkuki na Nyota, 2017), 86-93. 


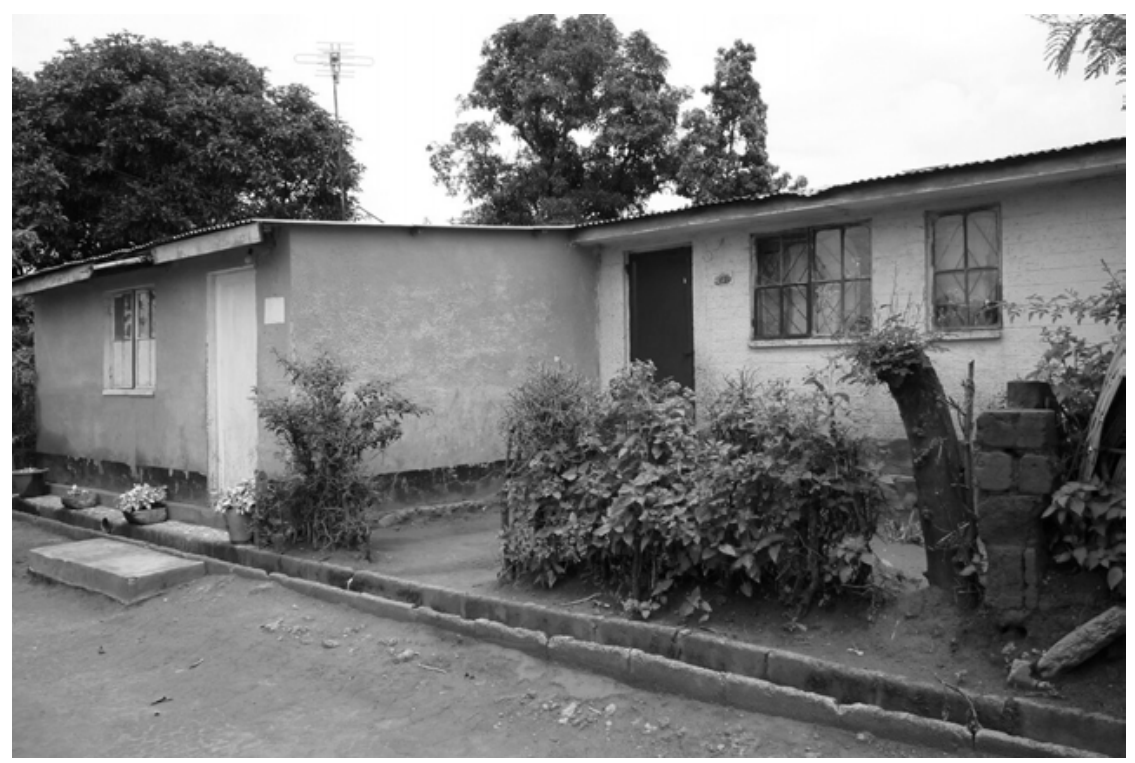

Figure 3.13: Transformation of an OCA house with an extra room added to the front, situation anno 2010.

Source: photograph by Céline Fenaux, 2010.

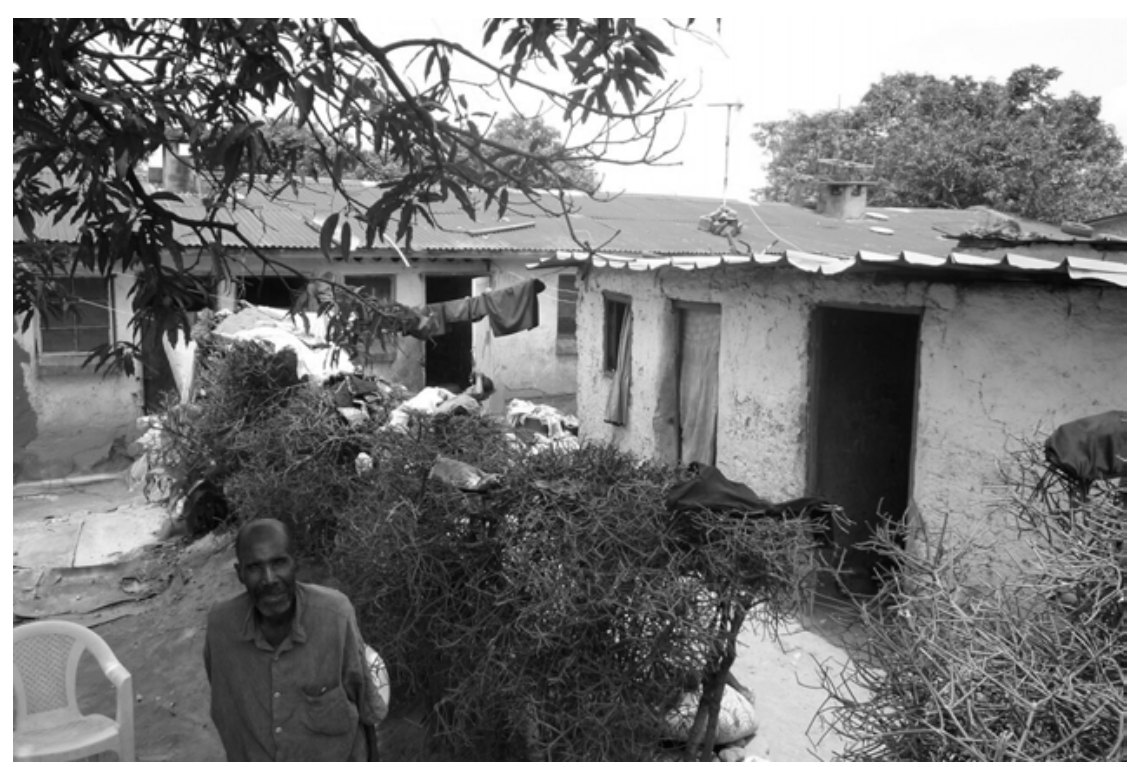

Figure 3.14: Transformation of an OCA house with an additional facility added to the back side. Source: photograph by Céline Fenaux, 2010. 
that during the turbulent events linked to Congo's struggle for independence, buildings constructed by the OCA in various cities fell victim to looting and destruction. ${ }^{49}$ Other historical research, especially by Congolese scholars, does not seem to corroborate such a reading. ${ }^{50}$ Today, as our fieldwork revealed, Ruashi is considered one of the more attractive areas in Lubumbashi to live in because it offers a less dense and more comfortable environment than in other parts of the city. Moreover, the transformations we described above are not unique to the OCA cités but also emerged, for instance, in the workers' camps of the railway company in Lubumbashi in 2006-2007, when the infrastructure was given to its employees to compensate for years of delay in paying their salary. ${ }^{51}$

Should the transformations made to the OCA houses in Ruashi then be read, if not as a deliberate act of resistance against a patronizing colonial policy of social engineering, then at least as a proof of the failure of the imported Western model of the one-family house, as Jacques Denis already seemed to suggest in $1958 ?^{52}$ For one thing, the sometimes radical transformations were surely not what the architects and planners of OCA had in mind, considering that even the type of la maison extensible was designed precisely to avoid the emergence of informal structures. We would like to offer a different reading here and argue that the spatial layout of the OCA cités and the architectural hardware of their houses actually offered inhabitants ample opportunities for changing their habitat and accommodating various arrangements of dwelling and occupation. ${ }^{53}$

49 De Meulder, Kuvuande Mbote, 204. See also his chapter in Tom Avermaete et al., Wonen in welvaart, 94-109.

50 No (strong) emphasis is put on the OCA cités in the context of Congo's struggle towards independence in the work of Congolese historians such as Isidore Ndaywel è Nziem, who wrote a general survey entitled Histoire générale du Congo: De l'héritage ancien à la République Démocratique (Paris: Duculot, 1998). Jean-Marie Mutamba Makombo Kitatshima, who authored an important study entitled Du Congo belge au Congo indépendant 1940-1960: Emergence des "évolués" et génèse du nationalisme (Kinshasa: IFEP, 1998); or Zana Etambala, who provided an account of the last years of colonial rule under the title De teloorgang van een modelkolonie: Belgisch Congo 1958-1960 (Leuven: Acco, 2008).

51 Fieldwork observations in the Camp Maramba by Johan Lagae in 2005, 2006, and 2010. A similar transformation took place recently in the Camp Kauka in Kinshasa, also exactly at the moment the railway company, or Office National du Transport (ONATRA), ceded the houses to its agents (fieldwork observation by Johan Lagae, 2017).

52 Denis, Le phénomène urbain en Afrique Centrale, 302-310.

53 The same phenomenon is to be seen in the OCA cités of Kinshasa and Kisangani. What seems apparent, however, is that the extent and nature of the transformations do differ in the various cities, with Kinshasa standing out because of more radical changes made to the urban landscapes of the OCA cités. 
It might be useful in this respect to bring to mind another, more well-known, case of a changed modern(ist) architectural landscape, the Cité Frugès in Pessac, near Bordeaux, which was built in 1925-1926 according to plans of Le Corbusier. Being one of the rare early projects in which Le Corbusier was able to test his innovative ideas on housing and urban planning, albeit still on a limited scale, this neighborhood has also become famous in architectural circles for the many transformations local inhabitants made in the course of time, thereby sometimes radically changing the architectural appearance that had been based on Le Corbusier's famous cinq points. Roof terraces, horizontal strip windows, and outdoor rooms all "fell victim" to different expectations of architect and inhabitants in terms of aesthetics, representation, and use. Confronted with this process, which led to some striking formal alterations of his initial architectural design, Le Corbusier is known to have reacted in a laconic way, stating that "la vie a toujours raison", "life is always right" and that it is "the architect who's wrong."

In his now classic book entitled Pessac de Le Corbusier: 1927-1967: Étude socio-architecturale, published originally in 1969, Philippe Boudon studied in detail the process of profound physical transformation that the houses of Le Corbusier underwent, reflecting on what was to be learned from this architecture habitée activement ("actively lived-in architecture"). Rather than regretting the process of radical transformation, Boudon argued that the modifications done to the architecture represented an "in the end positive rather than a negative sequence of the original architectural concept." 55 His view parallels that of architectural critic Ada Louise Huxtable who, after having visited the Cité Frugès in 1981, wrote in The New York Times that "contrary to popular belief and the conventional wisdom, it works." ${ }^{56}$ Pessac, Huxtable argued, was not "a testament to the miscarriage of modernism and the arrogance of its architects" but rather demonstrated that, despite "the loss of key elements of the Corbusian style," the settlement had "retained an impressive and recognizable integrity. Pessac was a very pleasant place to be. And these houses were clearly survivors." But, Huxtable added, "Pessac was a survivor precisely because of its architecture. Its strong identity absorbs almost anything." The

54 An early reference to this statement of Le Corbusier is to be found in the seminal monograph by Charles Jencks, Le Corbusier and the Tragic View of Architecture (Cambridge, Mass.: Harvard University Press, 1973), 74. The origin of this by now well-known and widespread quote is Philippe Boudon's study of Pessac: Boudon, Pessac de Le Corbusier, 2.

55 Boudon, Pessac de Le Corbusier, 167.

56 Ada Louise Huxtable, "Le Corbusier's Housing Project: Flexible Enough to Endure.” The New York Times, 15 May 1981. See Ada Louise Huxtable, On Architecture: Collected Reflections on a Century of Change (New York: Walker \& Company, 2008), 160-165. 
statement parallels the ones advanced by Boudon who wrote that the conclusion to be drawn from his study of the inhabitants' transformations was that the original architecture designed by Le Corbusier provided a clear "set of rules," or règles $d u$ jeu, which in terms of adaptation and transformation had proven to be "fruitful and full of opportunities." 57 Boudon went on to explain how this was mainly due to "standardization" and the particular relationship between closed and open forms, and between the inside and outside of the original architectural design. ${ }^{58}$ We argue that the design of the Ruashi neighborhood, and in extension all OCA cités, offers a similar open-ended "set of rules," as the spacious urban layout as well as the basic infrastructure of the OCA neighborhood (buildings as well as streets, squares, green spaces etc.) provided room for maneuver for a future transformation which is lacking in other cités indigènes in Lubumbashi, such as Kamalondo, Kenya and Katuba, where densities are higher, space is much more cramped and the architecture less imaginative and open-ended. By documenting the kind of "actively lived-in architecture" of Ruashi, our research aims at taking seriously what we can define, in line with Henri Lefebvre, as a praxis urbaine (or "urban praxis") of the Congolese inhabitants. ${ }^{59}$

Such an enterprise is all the more important and timely, as the OCA legacy is gaining currency as an important "colonial built heritage" in the former Belgian Congo, as is demonstrated by publications coming out of the milieu of heritage experts, be they French or Belgian. ${ }^{60}$ Defining the OCA cités as a "remarkable" example of modernist architecture in the Congo, heritage expert Yves Robert, for instance, wondered if their appropriation paved the way to a new form of patrimonialité (or "heritage practice"), adding that, as far as he was concerned, this was a question to which it is "too early to respond affirmatively." ${ }^{61}$ While we do underwrite the importance of rediscovering and documenting the legacy of colonial architecture in the Democratic Republic of the Congo, such as the OCA cités, we remain reluctant of efforts to define it in

57 Boudon, Pessac de Le Corbusier, 169.

58 Boudon, Pessac de Le Corbusier, 169-170.

59 In his preface to Philippe Boudon's book on Pessac, Lefebvre explicitly situates this study at the crossroads of architecture and urbanism, and presents it, more particularly, as an innovative analysis of praxis urbaine. Boudon, Pessac de Le Corbusier, viii. For Lefebvre's ideas on praxis urbaine and its links with Pessac, see Lukasz Stanek, Henri Lefebvre on Space: Architecture, Urban Research, and the Production of Theory (Minneapolis: University of Minnesota Press, 2011), especially Chapter 2 and, more in particular, 89-93.

60 See for instance Marc Pabois, ed., Lubumbashi: Capitale minière du Katanga 1910-2010: L'Architecture (Lubumbashi: Espace Culturel Francophone de Lubumbashi, 2008).

61 Yves Robert, “L'œuvre moderniste remarquable de l'Office des Cités Africaines au Congo," Les nouvelles du Patrimoine 128 (2010). 
terms of "heritage," let alone a "shared heritage."62 The last thing Ruashi needs, we would claim, is the kind of heritage make-over deployed in Le Corbusier's Pessac, where most of the houses have been restored to their original state. ${ }^{63}$ Cultural initiatives linked to urban heritage can act as important instruments of (re-)activating urban societies in a city like Lubumbashi. ${ }^{64}$ But the issue at stake in re-assessing a neighborhood like Ruashi today does not reside in celebrating and fixing it in time as a remarkable and forgotten modernist legacy but rather in trying to understand the complexities of this "actively lived-in architecture" in order to address the challenges its current inhabitants face in their everyday struggle for life.

As such, our position aligns with what Viviana d'Auria and Hannah Leroux have recently argued for in a theme issue of the journal Clara that they dedicated to the theme of "modernisme(s) approprié(s)" in its double meaning of both an "appropriate modernism," well-attuned to the local context, and a modernism that is "appropriated" by its users. ${ }^{65}$ In the editorial, they stress the need to analyze in detail the "encounter" between on the one hand "the residues of a utopic content that is intrinsically linked with the modernist project" and, on the other, "the appropriation of such places over time," as doing so can help us re-assess and gain a new understanding of "the urban phenomenon." words, what they argue for is a form of writing narratives on buildings that not only takes into consideration the origins of the design (and the way architects and planners tried to engage with the specificities of the local conditions), but also, and perhaps more importantly, the moment when life takes over (quand la vie prend le dessus). Ruashi, as we have tried to demonstrate here, is a case in point to do exactly that.

62 Johan Lagae and Sofie Boonen, "Décoloniser l'espace (péri)urbain en République Démocratique du Congo: Le cas de Lubumbashi," in Périurbains: Territoires, réseaux et temporalités, ed. Jean-Baptiste Minnaert (Lyon: Ed. Lieux Dits, 2013).

63 See for instance Bernard Toulier, Architecture et patrimoine du XXe siècle en France (Paris: Editions du Patrimoine, 1999), 60-63.

64 A fine example of such initiative is the cultural event Rencontres Picha, a bi-annual festival on contemporary photography and video art organized by two young artists from Lubumbashi, Patrick Mudekereza and Sammy Baloji, the second edition of which took place in October 2010, see Simon Njami, ed., Rencontres Picha: Biennale de Lubumbashi, 13-17 octobre 2010 (Paris: Filigraines édition, 2012), accessed October 17, 2017, online catalogue http://panicplatform.net/ content/curated/Catalogue\%20Picha\%202010.pdf.

65 Viviana d'Auria and Hannah Leroux, "Modernisme(s) approprié(s)," Clara 4 (2017). The cases presented in this theme issue range from modernist projects in Buenos Aires, Cape Town, Caracas, Seoul, Lima, Cansado-Zouerate (Mauritania), Benin, Hanoi and Brussels. 66 Viviana d'Auria and Hannah Leroux, "Modernisme(s) approprié(s)." 


\section{References}

\section{Archival sources}

The following files, held in the Africa Archives in Brussels, were consulted (these archives are now part of the State Archives, Brussels).

Portfolio GG.20.400 Fund Gouvernement Général.

Files 566, 567, 568, 569, portfolio 96 Fund Office des Cités Africaines.

Files 3012, 3019, portfolio 749 Fund Office des Cités Africaines.

File 1359, portfolio 270 Fund Office des Cités Africaines.

File 419, portfolio 70 Fund Office des Cités Africaines.

Color slide collection, Fund Office des Cités Africaines.

\section{Secondary literature}

Avermaete, Tom, et al., eds. Wonen in Welvaart: Woningbouw en wooncultuur in Vlaanderen 1948-1973. Antwerpen: deSingel, 2006.

Avermaete, Tom. "Framing the Afropolis: Michel Ecochard and the African City for the Greatest Number." Oase 82 (2010): 77-100.

Beeckmans, Luce, and Johan Lagae. "Kinshasa's Syndrome-planning in Historical Perspective: From Belgian Colonial Capital to Self-constructed Megalopolis." In Urban Planning in Sub-Saharan Africa: Colonial and Post-Colonial Planning Cultures, edited by Carlos Nunes Silva, 201-224. Abingdon: Routledge, 2015.

Boudon, Philippe. Pessac de Le Corbusier: 1927-1967: Étude socio-architecturale. Paris: Dunod, 1977.

Bruneau, Jean-Claude, and Marc Pain, eds. Atlas de Lubumbashi. Nanterre: Université de Paris X, Nanterre, 1990.

d'Auria, Viviana, and Hannah Leroux. “Modernisme(s) approprié(s).” Clara 4 (2017): 9-28.

De Meulder, Bruno. De Kampen van Kongo: Arbeid, kapitaal en rasveredeling in de koloniale planning. Amsterdam/Antwerpen: Meulenhoff/Kritak, 1996.

De Meulder, Bruno. Kuvuanda Mbote: Een eeuw architectuur en stedenbouw in Kongo. Antwerpen: Hautekiet/deSingel, 2000.

De Meulder, Bruno, and Marie-Françoise Plissart. "Kinshasa, the Hereafter of Modern Architecture." In Back from Utopia: The Challenge of the Modern Movement, edited by Hubert-Jan Henket and Hilde Heynen, 160-173. Rotterdam: 010 Publishers, 2002.

De Meulder, Bruno. "OCA (Office des Cités Africaines, 1952-1960) and the Urban Question in Central Africa.” Accessed October 17, 2017. https://archnet.org/system/publications/con tents/4922/original/DPC1635.pdf?1384787195.

Denis, Jacques. Le phénomène urbain en Afrique Centrale. Namur: FUNDP, n.d., 1958.

De Nys-Ketels, Simon. "Koloniaal beleid en stedelijke ruimte in een Congolese stad: De wijk Kenya in Lubumbashi, Congo.” Master diss., Ghent University, 2011.

de Saint-Moulin, Léon. Villes et organisation de l'espace en République Démocratique du Congo. Paris: L'Harmattan, 2010. 
Etambala, Zana. De teloorgang van een modelkolonie: Belgisch Congo 1958-1960. Leuven: Acco, 2008.

Fenaux, Céline. “L’Office des Cités Africaines in Lubumbashi. Ruashi: Architecturale analyse en studie van de toe-eigening van een Congolese wijk uit de jaren 1950." Master diss., Ghent University, 2010.

Fetter, Bruce. The Creation of Elisabethville, 1910-1940. Stanford: Hoover Institution Press, 1976.

Floré, Fredie, and Emiel De Kooning. "Post-war Model Homes: Introduction.” Journal of Architecture 4 (2004): 411-412.

Grévisse, Ferdinand. Le Centre Extra-Coutumier d'Elisabethville: Quelques aspects de la politique indigène du Haut-Katanga industriel. Brussels: Institut Royal Colonial Belge, 1950.

Hins, R. "L'Urbanisme au Katanga." Essor du Congo, Special edition on the occasion of the international exposition of Elisabethville, 1931 [n.p.].

Hunt, Nancy Rose. "Domesticity and Colonialism in Belgian Africa: Usumbura's Foyer Social, 1946-1960.” Signs 15 (1990): 447-474.

Huxtable, Ada Louise. "Le Corbusier's Housing Project: Flexible Enough to Endure.” The New York Times, May 15, 1981 (reprinted as "Flexible enough to endure" in Huxtable, Ada Louise. On Architecture: Collected Reflections on a Century of Change, 160-165. New York: Walker \& Company, 2008).

Lagae, Johan, Sofie Boonen, and Maarten Liefooghe. "Fissures dans le 'cordon sanitaire': Architecture hospitalière et ségrégation urbaine à Lubumbashi, 1920-1960.” In Lubumbashi: Cent d'ans d'histoire, edited by Maurice Amuri Mpala-Lutebele, 247-261. Paris: L'Harmattan, 2013.

Lagae, Johan, and Sofie Boonen. "Décoloniser l'espace (péri)urbain en République Démocratique du Congo: Le cas de Lubumbashi." In Périurbains: Territoires, réseaux et temporalités, edited by Jean-Baptiste Minnaert, 141-151. Lyon: Ed. Lieux Dits, 2013.

Lagae, Johan, Sofie Boonen, and Sam Lanckriet. "Navigating 'Off Radar': The Heritage of Liminal Spaces in the City Center of Colonial/Postcolonial Lubumbashi, DR Congo." In Things Don't Really Exist Until You Give Them A Name: Unpacking Urban Heritage, edited by Rachel Lee, Diane Barber, Anne-Katrin Fenk, and Philipp Misselwitz, 86-93. Dar es Salaam: Mkuki na Nyota, 2017.

Lejeune de Schiervel, Xavier. Les nouvelles cités congolaises: L'architecture et le logement. Brussels: Académie Royale des Sciences coloniales, 1956.

Lierman, Sally. "Office des Cités Africaines in Kisangani: Een stedenbouwkundig onderzoek naar genese en toe-eigening van een woonwijk uit de jaren 1950 in Afrika." Master diss., Ghent University, 2011.

Ministère des Colonies, ed. Plan décennal pour le Développement économique et social du Congo belge. Brussels: Les Editions de Visscher, 1949.

Mulumba, Crispin. "Origines et évolution des institutions communales et urbaines au Congo." Congo-Afrique 29 (1968): 449-457.

Mumford, Eric. The CIAM Discourse on Urbanism, 1928-1960. Cambridge: MIT Press, 2000.

Mutamba Makombo Kitatshima, Jean-Marie. Du Congo belge au Congo indépendant 1940-1960: Emergence des "évolués" et genèse du nationalisme. Kinshasa: Publications de l'Institut de formation et d'études politiques, 1998.

Ndaywel è Nziem, Isidore. Histoire générale du Congo de l'héritage ancien à la République Démocratique. Paris: Duculot, 1998. 
Nightingale, Carl. Segregation: A Global History of Divided Cities. Chicago: University of Chicago Press, 2012.

Pabois, Marc, ed. Lubumbashi: Capitale minière du Katanga 1910-2010: L'Architecture. Lubumbashi: Espace Culturel Francophone de Lubumbashi, 2008.

Pauwels, Dirk. "Souvenirs of Urbanism." In Brakin: Brazzaville - Kinshasa: Visualizing the Visible, edited by Wim Cuyvers, 245-263. Baden: Lars Müller Publishers, 2006.

Peigneux, Fernand. "De l'habitation." Bulletin de l'Union des Femmes Coloniales January 1954, 17. Plumier, Georges J., ed. Investir c'est prospérer: Les réalisations du Plan Décennal pour le Développement Economique et Social du Congo belge 1949-1959. Brussels: Imifi, 1959. Robert, Yves. "L'œuvre moderniste remarquable de l'Office des Cités Africaines au Congo." Les nouvelles du Patrimoine 128 (2010): 35-39.

Scaillon, Ernest. "La rénovation urbaine et l'unité de voisinage." Rythme 37 (1963): 10-12. Toulier, Bernard. Architecture et patrimoine du XXe siècle en France. Paris: Editions du Patrimoine, 1999.

Van der Woud, Auke. CIAM: Housing Town Planning. Delft: Delft University Press, 1983.

Vantemsche, Guy. “Le Plan Décennal et la modernization du Congo belge (1949-1959)." In La mémoire du Congo: Le temps colonial, edited by Jean-Luc Vellut, 104-107. Gent/ Tervuren: Snoeck/MRAC, 2005. 